\title{
Radioactive Effluents in the Savannah River Summary Report for 1993-1994
}

by

\author{
W. G. Winn
}

Westinghouse Savannah River Company

Savannah River Site

Aiken, South Carolina 29808

This paper was prepared in connection with work done under the above contract number with the U.S.

Department of Energy. By acceptance of this paper, the publisher and/or recipient acknowledges the U.S. Government's right to retain a nonexclusive, royalty-free license in and to any copyright covering this paper along with the right to reproduce and to authorize others to reproduce all or part of the copyrighted paper. 


\section{DISCLATMER}

This report was prepared as an account of work sponsored by an agency of the United States Government. Neither the United States Government nor any agency thereof, nor any of their employees, makes any warranty, express or implied, or assumes any legal liability or. -responsibility for the accuracy, completeness, or usefiulness of any information, apparatus, product, or process disclosed, or represents that its use would not infringe privately owned rights. Reference herein to any specific commercial product, process, or service by trade name, trademark, manufacturer, or otherwise does not necessarily constitute or imply its endorsement, recommendation, or favoring by the United States Government ar any agency thereof. The views and opinions of authors expressed herein do not necessarily state or reflect those of the United States Govemment or any agency thereof.

This report has been reproduced directly from the best available copy.

Available to DOE and DOE contractors from the Office of Scientific and Technical Information, P.O. Box 62, Oak Ridge, TN 37831; prices available from (615) 57.6-8401.

Available to the public from the National Technical. Information Service, U.S. Department of Commerce, 5285 Port Royal Road, Springfield, VA 22161. 


\section{DISCLAIMER}

Portions of this document may be illegible electronic image products. Images are produced from the best available original document. 


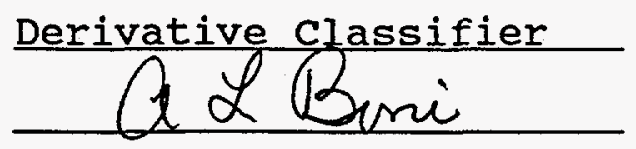

CC: SR-DOE

Keywords

Plant Vogtle

Savannah River

Effluent Releases

Isotopic Activities

DOE Guides

Gamma Spectrometry

HPGe Detectors

NaI(TI) Detectors

Liquid Scintillation

Lifetime Retention
S.R Wright, 703-41A

E.C. Goodson, 703-41A

K. Hooker, 703-41A

SRS L.M. Papouchado, 773-A

D.B. Moore-Shedrow, 773A

J.B. Gladden, 773-42A

A.L. Boni, 773-A

R.P. Addis, 773-A

W.H. Carlton, 773-A

W.A. Emel, 735-A

R.A. Sigg, 773-41A

K.J. Hofstetter, 735-A

K.W. MacMurdo, 735-A

M.M. Pendergast, 735-A

D.W. Hayes, 735-A

D.M. Beals, 735-A

J.R. Cadieux, 735-A

S:H. Reboul, 735-A

A.A. Simpkins, 773-A

D. Woodward, 703-A

D.A. Stevenson, $\mathrm{CCC}-4$

I.S. Roberts, 742-A

M.D. Dukes, 742-A

C.S. Hetrick, 735-A

J.D. Heffner, 735-15A

R.H. Young, 735-A

P.D. Fledderman, 735-A

T.S. DeHart, 735-A

B.C. Marcy, 773-42A

F.W. Whicker, 737-A

TIS File Copies (4)

March 17,1995
TO: J.E. HALVERSON
FROM: W.G. WINN $w / \not W$
Radioactive Effluents in Savannah River Summary Report for 1993-1994 (U)

(Cover Sheet) 


\section{Radioactive Effluents in Savannah River Summary Report for 1993-1994 (U)}

\section{Introduction}

During 1993-1994, low-level radiometric studies of the Savannah River continued to distinguish between effluent contributions from Plant Vogtle and the Savannah River site. Measurements of these radioactive effluents are of mutual interest to both institutions, as they can address abnormal trends before they become health and legal concerns.

The Environmental Technology section (ETS) has conducted radiometric studies of Plant Vogtle since late 1986 , prior to its startup [ref 1]. The plant has two 1100 MWe pressurized water reactors developed by Westinghouse. Unit 1 started commercial operations in June 1987, and Unit 2 began in May 1989. During powered operations, ETS has routinely detected neutron-activated isotopes in controlled releases [refs 2-7] but all activities have been orders of magnitude below the DOE guide values [ref 8 ] and EPA/CFR levels [ref 9]. In 1993-1994, Vogtle effluents continued to contribute low activities to the river. The Vogtle release data and the ETS measurements have tracked well over the past eight years. 
ETS ultra low-level radiometric measurement techniques are used in this work. In general, river samples are collected on resins, concentrated further in the lab, and then counted in the Underground counting Facility at 735-A [ref 10]. The bulk of the counting is by gamma spectrometry, but tritium is examined by liquid scintillation counting. The overall sampling/counting technique for gamma-ray analysis provides detection limits that are thousands of times lower than those routinely achievable. The tritium analysis also utilizes low-level detection sensitivity. An underwater NaI(Tl) detector at Hwy 301 Bridge provides continuous gamma monitoring of the Savannah River.

\section{Bummary}

During 1993-1994, the radioactive effluents in the Savannah River were comparable to those observed during the earlier years of these studies, generally remaining orders of magnitude below DOE and EPA/CFR guide levels. Vogtle had a few notable effluent releases in 1993-1994, producing higher river levels than those observed in the early 1990's. Vogtle effluents continue to be dominated by ${ }^{58} \mathrm{Co}$, which exhibited a maximum of $1.8 \mathrm{pCi} / \mathrm{L}$, which is only $1 / 10$ of the maximum observed earlier but is about 25 times the maximum observed in 1992 . In addition to ${ }_{65}^{58} \mathrm{Co}$, vogtle activities of ${ }^{51} \mathrm{Cr},{ }^{54} \mathrm{Mn},{ }^{57} \mathrm{Co},{ }^{59} \mathrm{Fe},{ }^{60} \mathrm{Co},{ }^{95} \mathrm{Nb}$, and ${ }^{95} \mathrm{Zr}$ were observed. Tritium and ${ }^{137} \mathrm{Cs}$ were also monitored, but their levels generally remain consistent with known SRS sources. However, the maximum tritium observed near vogtle was $64 \mathrm{pci} / \mathrm{mL}$. The maximum downstream tritium was lower at $7.5 \mathrm{pCi} / \mathrm{mL}$ and annual averages at Hwy 301 Bridge were 2.2-2.6 pci/mL. In addition to natural

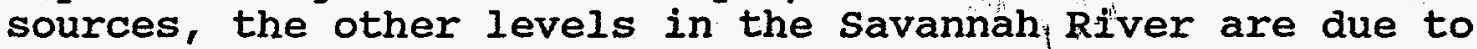
routine releases from the SRS Effluent Treatment Facility and seepage basin migration into plant streams flowing to the river.

\section{River sampling}

Samples were collected from the Savannah River at Shell Bluff, near the Vogtle outfall, and at Hwy 301 bridge. Activities measured just upstream and downstream of the vogtle outfall identify contributions from that plant alone. specifically, samples were taken $0.3 \mathrm{mi}$ above, $0.1 \mathrm{mi}$ below, and at the Vogtle outfall. The SRS effluents are deduced primarily from the activities upstream/downstream of SRS at Shell Bluff/HwY 301 bridge. A map of the sampling sites is given in the appendix.

Resih, water, and sediment samples were collected using methods detáiled in the Vogtle pre-start study [ref 1]. Each resin concentrator sample consists of $\approx 25 \mathrm{~g}$ of resin in a porous nylon bag (except during a 4-month period when $\approx 10 \mathrm{~g}$ was used due to Iimited supply). The samplers were in the river for two weeks, after which they were retrieved and returned to the lab. 
Water samples were collected directly, and sediment samples were scooped into a specially designed sampler pulled along the bottom of the river.

\section{Laboratory Measurements}

The resin concentrator samples provide the most comprehensive isotopic information. Each of these samples was dried and ashed, leaving a smaller volume and thus better counting geometry for the HPGe detector. Typically, two HPGe detectors, with ${ }^{60} \mathrm{Co}$ standard efficiencies of $20 \%$ and $25 \%$, were used in counting these samples; both are located in the Underground Counting Facility. Also, a larger detector with ${ }^{60} \mathrm{Co}$ standard efficiency of $90 \%$ and an active/passive shield has been calibrated to examine these samples. Samples were counted overnight (or over the weekend) to assure good counting statistics for detecting low-level activities. The resulting HPGe gamma-ray spectra are analyzed with an IBM/PC-XT using the GRABGAM code [ref 10] to yield the activity (fCi) of each isotope detected in the resin sample. The average isotopic concentration (fCi/L) for the collection period is obtained by using empirical calibration data that relate the resin mass and collection time to the effective water volume (I).

The water samples were examined for tritium by liquid scintillation counting. A TRICARB ${ }^{\text {TM }}$ LL 2050A low-level Iiquid scintillation analyzer was used. Vials with $3 \mathrm{~mL}$ of sample and $20 \mathrm{~mL}$ of OPTI-FLUOR ${ }^{T M}$ scintillant were counted. Duplicate samples with $0.25 \mathrm{~mL}$ of tritium standard checked that the automatic quench corrections were being performed accurately.

Sediment samples were dried to constant weight and transferred to 1-L Marinelli beakers for counting on the HPGe detectors. The sample isotopic activities (fCi) from the gammaray analysis are divided by the dry weight $(\mathrm{g})$ of each sample to $y$ ield the corresponding concentrations ( $\mathrm{fCi} / \mathrm{g}$ ).

\section{Underwater NaI(TI) Measurements}

The underwater NaI(TI) detector operates from a floating platform anchored near Hwy 301 bridge. The unit has a 9 " diameter by 4" long NaI(TI) detector, four photo-multiplier tubes, and a high voltage/preamp unit - all contained in a waterproof stainless steel housing. The detector views its surroundings through a thin hemispherical dome.

The detector receives operating power via a waterproof cable connected to $a \approx 25 \mathrm{~V}$ DC supply in the cabin of the pontoon boat. A unit within the detector assembly boosts this voltage to about $1000 \mathrm{~V}$ for photo-tube operation. The AC-coupled detector signals 
are transmitted via the same cable to the cabin, where they are amplified and input to a multichannel analyzer.

Spectral data are collected on the multichannel analyzer, which comprises a COMPAQ 286 computer and an ACE MCA card from EG\&G ORTEC. Spectra are stored on floppy disk in sequenced 24-hr periods for 2-3 weeks. The disks are retrieved and analyzed at the laboratory. This detector system provides better time resolution ( 1 day) than the resin concentrator method (2 weeks), but its sensitivity is lower by more than an order of magnitude [refs 11,12$]$.

The performance of the underwater NaI detector during 19871992 illustrates that it has tracked the notable Vogtle releases quite reliably by its detection of ${ }^{58} \mathrm{Co}$ [ref 11,12$]$. By contrast, the NaI detector did not readily observe sRS effluents during this period, as concentrations of the dominant ${ }^{137} \mathrm{Cs}$ of SRS river effluents were below the detection limit for the NaI detector.

\section{Results}

The resin sampler analyses continued to indicate ${ }^{58} \mathrm{Co}$,
and ${ }^{137} \mathrm{Cs}$, the most significant gamma-emitting radionuclides detected in the earlier studies [refs 2-7]. The 1993-1994 results for these isotopes are given in Tables 1-3, along with plots in Figures 1-3. The other detected manmade gamma-emitting radionuclides are given in Table 4, where they are compared with the ${ }^{58} \mathrm{Co}$ levels.

For the resin results, it should be noted that the ${ }^{137} \mathrm{Cs}$ value below Vogtle for 11/02-11/16/93 was"suspiciously high, which was considered due to an abnormally low recorded resin mass of $0.91 \mathrm{~g}$. A review of the pre/post-ashed sample mass data suggested a more typical resin mass of $22.5 \mathrm{~g}$, and this mass yielded a realistic ${ }^{137} \mathrm{Cs}$ concentration. According, all results for 11/02-11/16/93 were lowered by a factor of $0.91 / 22.5$.

Water analysis for tritium followed techniques used earlier [ref 1,2$]$. The 1993-1994 results are summarized in Table 5 .

Sediments were analyzed for ${ }^{58} \mathrm{Co},{ }^{60} \mathrm{Co}$, and ${ }^{137} \mathrm{Cs}$ to appraise whether significant deposition is occurring during the transport of these isotopes in river water. The corresponding results are shown in Table 6 .

Data for the underwater NaI(Tl) detector are presented in Figures 4 and 5 . Figure 4 is an isometric plot of count rate vs gamma energy and date. Figure 5 compares the ${ }^{58}$ Co detected by the underwater NaI(TI) with that detected with the resin concentrator samples. The measurements yielded only sparse data during September and october of 1993, due to failure of three of the 
four photomultiplier tubes, apparently caused by electrical surges during a storm. The faulty tubes were replaced and the monitor was returned to service in November. Operations then continued through April of 1994, at which time the floating platform was removed for replacement due to its deteriorating condition concerning safe operations. The replacement platform was received near the end of 1994 and is to be installed in 1995.

\section{Discussion}

River water levels

In 1993-1994, the earlier decreasing trend [ref 7] of manmade radioactivity in the Savannah River was interrupted as Plant Vogtle had a few significant effluent releases. At the same time, these releases produced manmade radionuclide water concentrations that were only $1 / 10$ of the overall maximum during study, which occurred in 1988 [ref 3]. Referring to Table 4, the water samples showed that Vogtle effluents contained all radionuclides detected in earlier years $-{ }^{51} \mathrm{Cr},{ }^{54} \mathrm{Mn},{ }^{57} \mathrm{Co},{ }^{58} \mathrm{Co}$, ${ }^{59} \mathrm{Fe},{ }^{60} \mathrm{Co},{ }^{95} \mathrm{Nb}$, and ${ }^{95} \mathrm{Zr}$. The Vogtle effluents continue to be dominated by ${ }^{58} \mathrm{Co}$, which exhibited a maximum concentration of 1.8 $\mathrm{pCi} / \mathrm{L}$ during 1993-1994. The activities of the above radionuclides are reasonably consistent with vogtle data for their effluent discharges in 1993-1994; however, a release in November 1994 was not detected well, similar to an earlier release in March 1990 where depletion in transport was suspected [refs 11-12].

SRS radionuclides ${ }^{3} \mathrm{H},{ }^{60} \mathrm{Co}$, and ${ }^{137} \mathrm{Cs}$ accounted for the other manmade radionuclides observed in the river water, but their concentrations have remained essentially consistent with those measured prior to vogtle startup in 1987 . The overall ${ }^{3} \mathrm{H}$ concentrations for 1993-1994 were also comparable to those observed in earlier years, having an average of $2.2 \mathrm{pCi} / \mathrm{mL}$ at Hwy 301 Bridge. However, a single occurrence of about $60 \mathrm{pci} / \mathrm{mL}$ at and below the vogtle outfall was witnessed for the $6 / 14 / 94$ samples. Comparably high values had been observed previously on $10 / 22 / 87$ and $9 / 13 / 90$, and in all three instances the ${ }^{3} \mathrm{H}$ appears to be from Vogtle as no ${ }^{3} \mathrm{H}$ was observed immediately upstream. The SRS ${ }^{60} \mathrm{Co}$ is only a fraction of the Vogtle ${ }^{60} \mathrm{Co}$, as noted by the largest ${ }^{60} \mathrm{Co}$ levels, which were measured immediately down stream of the vogtle outfall. The ${ }^{137} \mathrm{Cs}$ concentrations in the river are primarily due to SRS sources. At HwY 301 Bridge, ${ }^{137} \mathrm{Cs}$ averaged $20 \mathrm{fCi} / \mathrm{L}$, which remains consistent with sRs being the dominant source.

Contrary to the earlier releases, the activities did not show strong evidence of migration downstream to Hwy 301 Bridge. The 1993-1994 release activities near Plant vogtle were reduced by a factor of about $1 / 100$ by the time they reached Hwy 301 Bridge, whereas the reduction factor was generally only about 
$1 / 10$ during earlier releases. Part of this decrease may be due to the overall greater water volume of the river during 1993-1994, causing both dilution and better flow dispersion. Vogtle reported no recent changes in the nature of their effluent releases that would explain this, although the last measurable decrease, which occurred in December 1991, was about 1/30, suggesting that earlier changes in effluent processing may be partly responsible. Indeed, the possibility of depletion in transport has been noted [refs 11-12]. Future attention will be focused on better resolution of this issue during the continuation of these studies.

Sediment Levels

The sediment samples frequently exhibited ${ }^{137} \mathrm{Cs}$, but only one occurrence of ${ }^{58} \mathrm{Co}$ and ${ }^{60} \mathrm{Co}$ [Table 6]. Overall activities observed in 1993-1994 are comparable to those observed in earlier years [refs 2-7]. The largest ${ }^{137} \mathrm{Cs}$ activities were observed at HWy 301 Bridge, having an average of $107 \mathrm{pci} / \mathrm{kg}$ sediment. Activities for ${ }^{58} \mathrm{Co}$ and ${ }^{60} \mathrm{Co}$ were observed only in the $11 / 9 / 93$ sample from Hwy 301 Bridge, with each isotope showing about $30 \mathrm{pCi} / \mathrm{kg}$. Such large concentrations of ${ }^{58} \mathrm{Co}$ and ${ }^{60} \mathrm{Co}$ at Hwy 301 Bridge are unique relative to the earlier studies, which had values below 10 $\mathrm{pCi} / \mathrm{kg}$; however, the $284 \mathrm{pCi} / \mathrm{kg}{ }^{137} \mathrm{Cs}$ observed in the same sediment sample is typical of levels at Hwy 301 Bridge, which have been an order of magnitude greater than those at the other sampling locations [refs 2-7]. A candidate explanation of the single observation of the unusually high ${ }^{58} \mathrm{Co}$ and ${ }^{60} \mathrm{Co}$ is a "hot" particle(s) that moved down stream from Vogtle, which is the only currently known source for short-lived $\left(T_{1 / 2}=71\right.$ days $){ }^{58} \mathrm{Co}$.

\section{Underwater NaI}

The underwater NaI(TI) detector at HwY 301 Bridge continued to monitor Plant Vogtle effluents by detection of the ${ }^{58} \mathrm{Co}$ activity [refs 11-12]. An isometric plot of count rate vs gamma energy and time is given in Figure 4, where the peak near $800 \mathrm{keV}$ is identified with the $811 \mathrm{keV}$ gamma of ${ }^{58} \mathrm{Co}$. Figure 5 compares a time plot of this peak with a similar one for ${ }^{58}$ Co concentrations measured with the resin samples. In 1993-1994 only very low levels of ${ }^{58} \mathrm{Co}$ were observed at Hwy 301 Bridge, as illustrated by the data for the two profiles. Unfortunately, the downtime of the underwater detector limited the comparison, and the available data had activities that were too low to demonstrate a clear correlation between the two profiles, as had been accomplished in earlier years. Also, for the underwater NaI(TI) detector, the 795 $\mathrm{keV}$ gamma of naturally occurring ${ }^{228} \mathrm{AC}$ contributes to the peak near $800 \mathrm{keV}$ in the spectra, due to resolution limits [ref 4]. No such resolution problem existed for the resin samples because they were counted on HPGe detectors. Thus in Figure 5, the underwater NaI(Tl) plot of Co-58 includes a background component whereas the corresponding plot for HPGe-counted resins does not. 


\section{Drinking water Guides}

Table 7 compares the maximum-detected river concentrations with the DOE guide limits for drinking water [refs 8] along with similar EPA/CFR guide limits [ref 9]. All concentrations are well below these guide limits. Furthermore, the table compares the maximum concentrations in 1993-1994 with those of earlier years. All measured radionuclide concentrations are well below DOE and EPA/CFR guides for drinking water, as shown in Table 7.

\section{Continuation of study}

These studies have: continuously monitored the Savannah River since their inception in 1986. They are continuing on a routine basis, as they provide early detection/correction of abnormal trends before actual health and legal concerns evolve. The program is mutually beneficial to both Vogtle and SRS, and cooperative efforts between the two sites continue to enhance the measurements program.

\section{Acknowledgements}

The author wishes to thank Shan Sundaram and H.T. Wilson for their support in this study. Shan sunderam of Plant vogtle has continued to provide useful information on their releases. H.T. Wilson coordinated the river sampling program and analyzed the bulk of the samples in the Underground counting Facility. Also, the sample collections group of R.R. Penix, R.J. Roseberry, and A.B. Antonicelli are thanked for their supporting role. 


\section{References}

1. R.A. Sigg and W.G. Winn, Pre-operational Radio-Environmental Studies of Plant Vogtle, WSRC-RP-89-161, May 1, 1989.

2. W.G. Winn, Radioactive Effluents in the Savannah River Summary Report for 1987, DPST-88-605, June 3, 1988.

3. W.G. Winn, Radioactive Effluents in the Savannah River Summary Report for 1988, DPST-89-318, February 22, 1989.

4. W.G. Winn, Radioactive Effluents in the Savannah River Summary Report for 1989, WSRC-TR-90-245, June 8, 1990.

5. W.G. Winn, Radioactive Effluents in the Savannah River Summary Report for 1990, WSRC-TR-91-647, November 27, 1991.

6. W.G. Winn, Radioactive Effluents in the Savannah River Summary Report for 1991, WSRC-TR-92-365, July 16, 1992.

7. W.G. Winn, Radioactive Effluents in the Savannah River Summary Report for 1992, WSRC-TR-93-473, September 21, 1993.

8. Department of Energy Order DOE 5484.1 (Draft 1986).

9. Savannah River Site Environmental Report for 1993, WSRC-TR94-075, Appendix D.

10. W.G. Winn, W.W. Bowman, and A.L. Boní, Ultra-clean Underground counting Facility for "Low-Level Environmental Samples, DP-1747, September 1987.

11. W.G. Winn and Shan Sundaram, "Verification of Reactor Effluent Releases with an Underwater NaI Detector", Proceedings of ANS Topical Meeting on Environmental Transport and Dosimetry (Charleston, SC, September 1-3, 1993), pp 101-103.

12. W.G. Winn, Environmental Measurements at the Savannah River Site with Underwater Gamma Detectors, WSRC-MS-93-437, to be published in Journal of Radioanalytical Chemistry. 
Table 1. Co-58 Concentrations in 1993-1994

(Values in $\mathrm{fCi} / \mathrm{L})^{\mathrm{a}}$

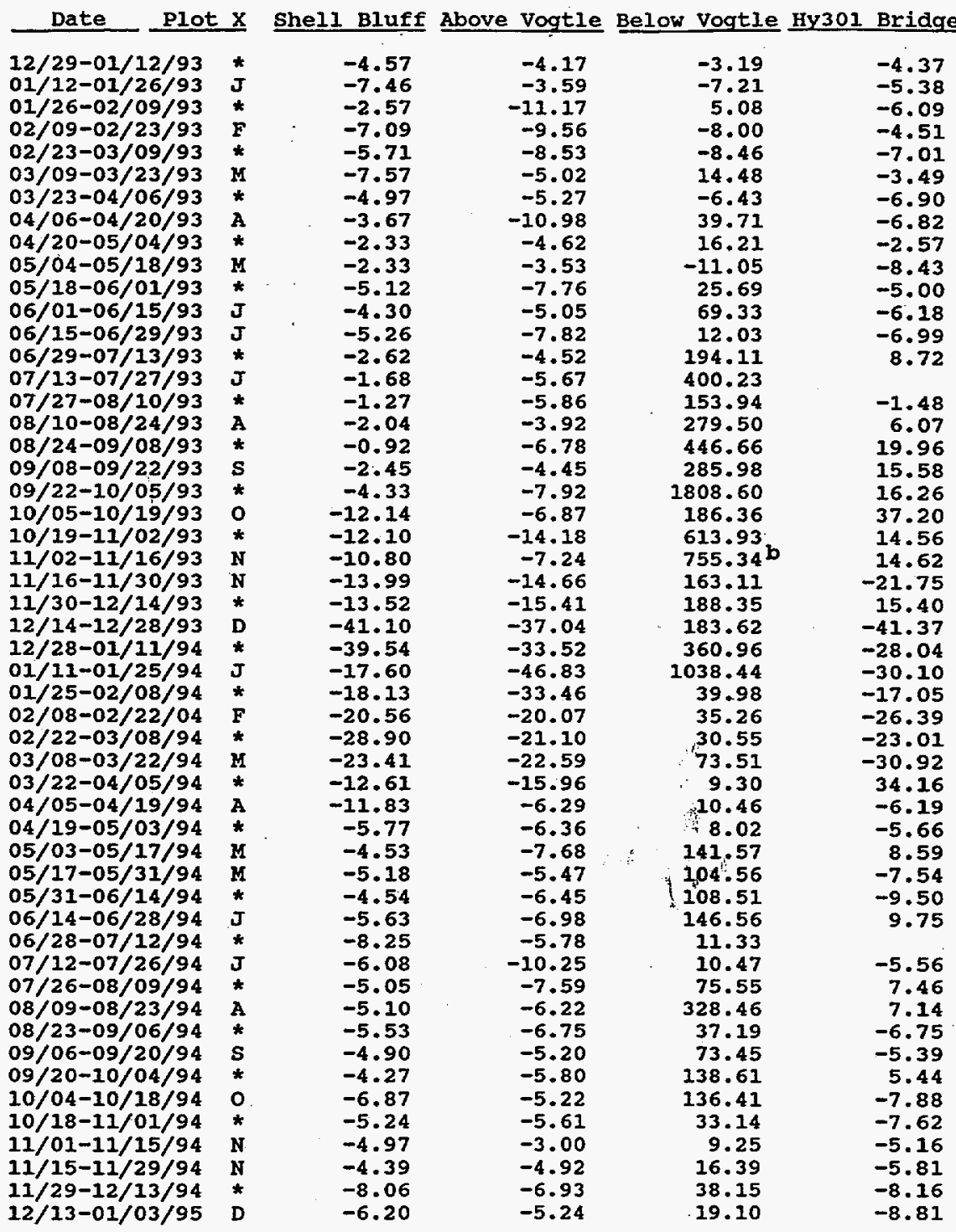

a) Counting error estimated at $\leq 0.82 \mathrm{~V}$ where $\mathrm{V}$ is entry value. Values with minus(-) are minimum detectable amounts or MDAs. The error estimate should be tripled for samples during 10/05/93-04/05/94 to account for smaller resin samples $(\approx 10 \mathrm{~g}$ vs usual $\approx 25 \mathrm{~g})$ used due to a temporary supply shortage.

b) Corrected per discussion in Results section. 
Table 2. Co-60 Concentrations in 1993-1994

(Values in $\mathrm{fCi} / \mathrm{L})^{\mathrm{a}}$

Date Plot $x$ Shell Bluff Above Vogtle Below Vogtle Hy301 Bridge

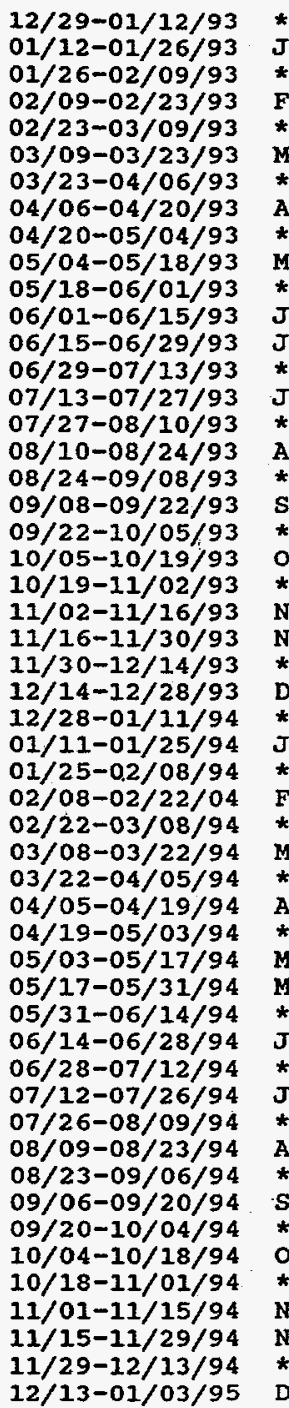

$$
\begin{aligned}
& -2.90 \\
& -7.10 \\
& -2.50 \\
& -6.60 \\
& -5.30 \\
& -8.30 \\
& -4.50 \\
& -3.80 \\
& -2.30 \\
& -2.40 \\
& -4.00 \\
& -3.70 \\
& -0.47 \\
& -2.40 \\
& -1.20 \\
& -1.10 \\
& -1.20 \\
& -0.60 \\
& -2.00 \\
& -4.40 \\
& -10.00 \\
& -10.60 \\
& -7.10 \\
& -8.80 \\
& -9.60 \\
& -24.80 \\
& -23.60 \\
& -12.50 \\
& -11.70 \\
& -10.40 \\
& -19.90 \\
& -17.10 \\
& -8.60 \\
& -9.10 \\
& -4.90 \\
& -3.60 \\
& -4.50 \\
& -3.50 \\
& -4.70 \\
& -8.20 \\
& -5.20 \\
& -5.20 \\
& -4.80 \\
& -5.50 \\
& -4.60 \\
& -3.70 \\
& -6.90 \\
& -5.80 \\
& -5.60 \\
& -5.00 \\
& -6.10 \\
& -4.50
\end{aligned}
$$

\section{$-4.00$}

$-3.10$

$-10.30$

$-9.50$

$-8.10$

$-4.90$

$-5.00$

$-9.10$

$-4.50$

$-2.90$

$-6.70$

$-4.00$

$-0.69$

$-4.20$

$-4.40$

$-4.20$

$-0.58$

$-3.50$

$-7.40$

$-5.30$

$-4.70$

$-4.80$

$-8.60$

$-10.50$

$-21.90$

$-17.70$

$-26.40$

$-18.90$

$-11.10$

$-13.40$

$-13.30$

$-10.10$

$-4.40$

$-4.80$

$-5.70$

$-4.90$

$-5.80$

$-6.00$

$-7.90$

$-7.50$

$-6.00$

$-5.70$

$-4.70$

$-5.40$

$-5.00$

$-5.20$

$-3.00$

$-4.50$

$-5.20$

$-4.10$

$$
\begin{array}{r}
-2.50 \\
-5.50 \\
-3.30 \\
-7.50 \\
-7.90 \\
-10.50 \\
-5.60 \\
28.50 \\
7.90 \\
-8.00 \\
8.70 \\
14.10 \\
10.70 \\
88.40 \\
144.10 \\
48.60 \\
249.40 \\
393.70 \\
405.10 \\
398.00 \\
70.90 \\
128.30 \\
252.84 \\
49.90 \\
104.20 \\
136.70 \\
284.60 \\
419.20 \\
22.70 \\
23.50 \\
61.30 \\
127.00 \\
30.00 \\
13.40 .40 \\
31.10 \\
14.20 \\
21.10 \\
278.00 \\
225.50 \\
496.40 \\
157.20 \\
71.80 \\
34.90 \\
175.30 \\
263.20 \\
55.70 \\
52.00 \\
56.30 \\
60.30 \\
21.20 \\
9.60 \\
10
\end{array}
$$

$$
\begin{array}{r}
-3.80 \\
-4.50 \\
-5.50 \\
-4.10 \\
-7.20 \\
-3.30 \\
-6.40 \\
-6.50 \\
-1.90 \\
-6.90 \\
-4.20 \\
-6.30 \\
-6.00 \\
5.10 \\
7.50 \\
5.60 \\
29.00 \\
21.60 \\
-4.80 \\
-12.10 \\
-10.00 \\
-7.30 \\
15.10 \\
16.20 \\
-37.10 \\
-17.90 \\
-78.60 \\
-5.40 \\
-5.80 \\
-6.30 \\
-15.20 \\
-15.30 \\
-13.40 \\
-24.70 \\
25.00 \\
-5.10 \\
-4.60 \\
15.50 \\
15.30 \\
32.60 \\
22.60 \\
10.10 \\
20.30 \\
32.60 \\
-6.80 \\
-4.90 \\
-4.60 \\
-60
\end{array}
$$

a) Counting error estimated at $\leq 0.75 \mathrm{~V}$ where $\mathrm{V}$ is entry value. Values with minus(-) are minimum detectable amounts or MDAs. The error estimate should be tripled for samples during 10/05/93-04/05/94 to account for smaller resin samples $(\approx 10 \mathrm{~g}$ vs usual $\approx 25 \mathrm{~g})$ used due to a temporary supply shortage.

b) Corrected per discussion in Results section. 
Table 3. Cs-137 Concentrations in 1993-1994

(Values in $\mathrm{fCi} / \mathrm{L})^{\mathrm{a}}$

Date Plot $x$ Shell Bluff Above Vogtle Below Vogtle Hy301 Bridge

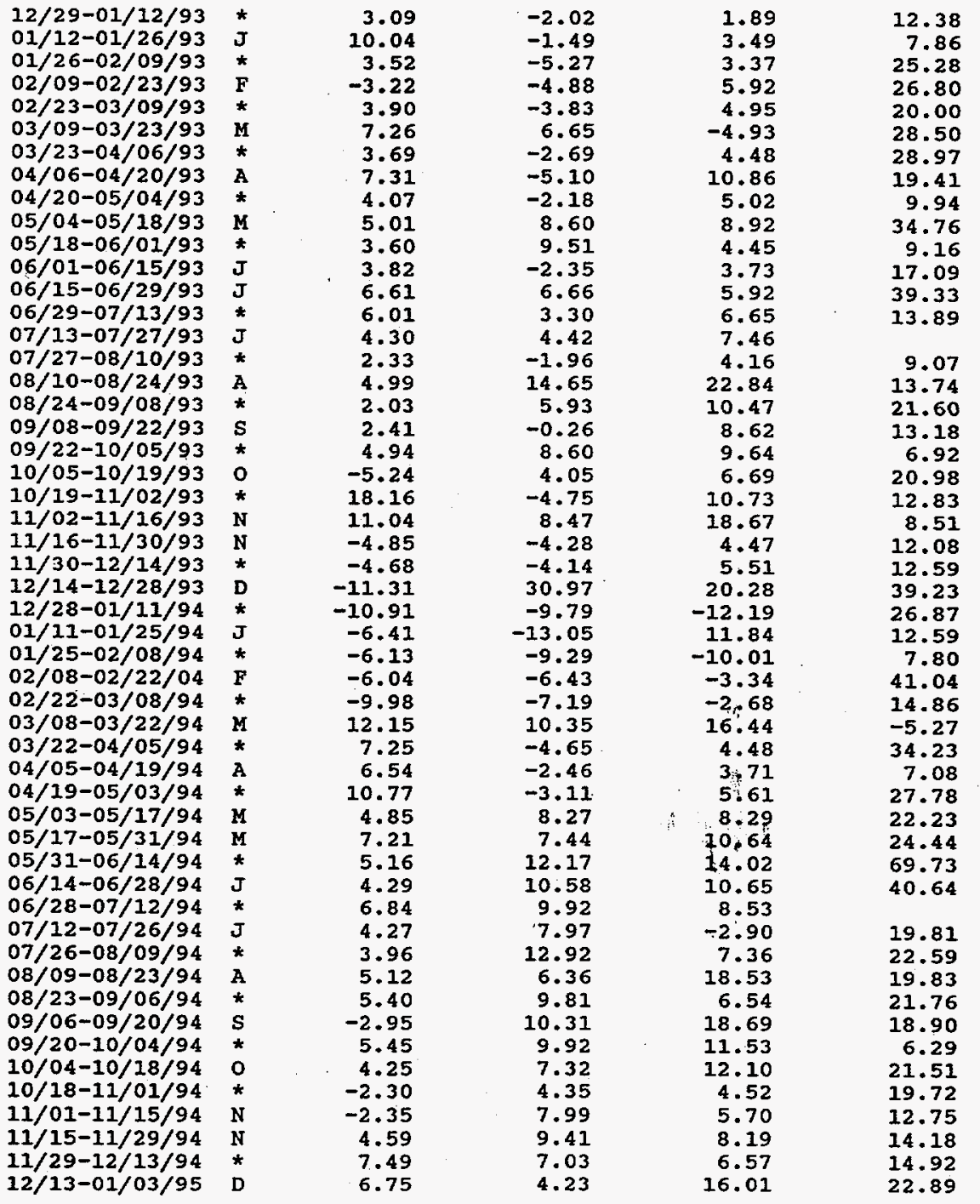

a) Counting error estimated at $\leq 0.58 \mathrm{~V}$ where $\mathrm{V}$ is entry value. Values with minus(-) are minimum detectable amounts or MDAs. The error estimate should be tripled for samples during 10/05/93-04/05/94 to account for smaller resin samples $(\approx 10 \mathrm{~g}$ vs usual $\approx 25 \mathrm{~g})$ used due to a temporary supply shortage.

b) Corrected per discussion in Results section. 
Table 4. Relative Isotopics Below Vogtle During 1993-1994a,b

(Sample site $0.1 \mathrm{mi}$ downstream of Vogtle)

Date
$12 / 29-01 / 12 / 93$
$01 / 12-01 / 26 / 93$
$01 / 26-02 / 09 / 93$
$02 / 09-02 / 23 / 93$
$02 / 23-03 / 09 / 93$
$03 / 09-03 / 23 / 93$
$03 / 23-04 / 06 / 93$
$04 / 06-04 / 20 / 93$
$04 / 20-05 / 04 / 93$
$05 / 04-05 / 18 / 93$
$05 / 18-06 / 01 / 93$
$06 / 01-06 / 15 / 93$
$06 / 15-06 / 29 / 93$
$06 / 29-07 / 13 / 93$
$07 / 13-07 / 27 / 93$
$07 / 27-08 / 10 / 93$
$08 / 10-08 / 24 / 93$
$08 / 24-09 / 08 / 93$
$09 / 08-09 / 22 / 93$
$09 / 22-10 / 05 / 93$
$10 / 05-10 / 19 / 93$
$10 / 19-11 / 02 / 93$
$11 / 02-11 / 16 / 93$
$11 / 16-11 / 30 / 93$
$11 / 30-12 / 14 / 93$
$12 / 14-12 / 28 / 93$
$12 / 28-01 / 11 / 94$
$01 / 11-01 / 25 / 94$
$01 / 25-02 / 08 / 94$
$02 / 08-02 / 22 / 04$
$02 / 22-03 / 08 / 94$
$03 / 08-03 / 22 / 94$
$03 / 22-04 / 05 / 94$
$04 / 05-04 / 19 / 94$
$04 / 19-05 / 03 / 94$
$05 / 03-05 / 17 / 94$
$05 / 17-05 / 31 / 94$
$05 / 31-06 / 14 / 94$
$06 / 14-06 / 28 / 94$
$06 / 28-07 / 12 / 94$
$07 / 12-07 / 26 / 94$
$07 / 26-08 / 09 / 94$
$08 / 09-08 / 23 / 94$
$08 / 23-09 / 06 / 94$
$09 / 06-09 / 20 / 94$
$09 / 20-10 / 04 / 94$
$10 / 04-10 / 18 / 94$
$10 / 18-11 / 01 / 94$
$11 / 01-11 / 15 / 94$
$11 / 15-11 / 29 / 94$
$11 / 29-12 / 13 / 94$
$12 / 13-01 / 03 / 95$

cr-51

Isotopics
Mn-54
Co-57 Co-58 Activity below Vogtle
Co-58

$12 / 29-01 / 12 / 93$

$01 / 12-01 / 26 / 93$

$02 / 09-02 / 23 / 93$

$02 / 23-03 / 09 / 93$

$03 / 09-03 / 23 / 93$

$04 / 06-04 / 20 / 93$

$04 / 06-04 / 20 / 93$

$05 / 04-05 / 18 / 93$

$06 / 01-06 / 15 / 93$

06/15-06/29/93

06/29-07/13/93

$07 / 27-08 / 10 / 93$

$08 / 10-08 / 24 / 93$

源

$09 / 22-10 / 05 / 93$

10/05-10/19/93

11/02-11/16/9

$11 / 16-11 / 30 / 93$

$11 / 30-12 / 14 / 93$

12/28-01/11/94

$11-01 / 25 / 94$

$2 / 22-03 / 08 / 94$

(08-03/22/94

$04 / 05-04 / 19 / 9$

$04 / 19-05 / 03 / 94$

5 $/ 03-05 / 17 / 94$

$05 / 31-06 / 14 / 94$

$06 / 14-06 / 28 / 94$

$07 / 26-08 / 09 / 9$

济

$-09 / 20 / 94$

/04/9

10/18-11/01/9

$1 / 15-11 / 29 / 9$

$12 / 13-01 / 03 / 95$

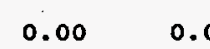

$0.00 \quad 0.00$

$0.00 \quad 87.04$

$0.00 \quad 0.00$

$0.00 \quad 0.00$

$0.00 \quad 0.00$

$0.00 \quad 0.00$

$0.00 \quad-15.82$

$0.00 \quad 0.00$

$\begin{array}{ll}0.000 & 0.00 \\ 0.00 & 0.00\end{array}$

$\begin{array}{ll}0.00 & 0.00 \\ 0.00 & 9.74\end{array}$

$0.00 \quad 0.00$

$0.00 \quad 15.21$

$\begin{array}{ll}0.00 & 15.21 \\ 0.00 & 10.76\end{array}$

$\begin{array}{ll}0.00 & 10.76 \\ 0.00 & 21.92\end{array}$

$0.00 \quad 24.47$

$50.23 \quad 18.75$

$55.65 \quad 9.61$

$\begin{array}{rr}0.00 & 11.52 \\ 0.00 & 6.71\end{array}$

$\begin{array}{rr}0.00 & 6.71 \\ 36.73 & 12.59\end{array}$

$\begin{array}{rr}36.73 & 12.59 \\ 0.00 & 8.72\end{array}$

$0.00 \quad 15.01$

$0.00 \quad 19.84$

$\begin{array}{ll}0.00 & 12.67 \\ 0.00 & 12.11\end{array}$

$\begin{array}{rr}0.00 & 12.11 \\ 0.00 & 0.00\end{array}$

$0.00 \quad 27.16$
0.00

$0.00 \quad 0.00$

$\begin{array}{lr}0.00 & -31.07 \\ 0.00 & 0.00\end{array}$

$0.00 \quad 0.00$

$0.00 \quad 29.52$

$0.00 \quad 62.78$

$0.00 \quad 60.16$

$0.00 \quad 21.45$

$0.00 \quad 120.69$

$0.00 \quad 62.39$

$0.00 \quad 52.93$

$0.00 \quad 28.90$

$0.00 \quad 26.88$

$0.00 \quad 16.74$

$31.83 \quad 10.98$

$65.81 \quad 14.90$

$-78.65 \quad 32.02$

$0.00-29.35$

$\begin{array}{ll}0.00 & 25.14 \\ 0.00 & 20.61\end{array}$

$\begin{array}{rr}0.00 & 20.61 \\ 0.00 & 0.00\end{array}$

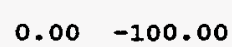

$\begin{array}{lr}0.00 & -100.00 \\ 0.00 & -100.00 \\ 0.00 & 100.00\end{array}$

$\begin{array}{rr}0.00 & -100.00 \\ 0.00 & -100.00\end{array}$

$\begin{array}{ll}0.00 & -100.00 \\ 0.00 & -100.00\end{array}$

$0.00 \quad 100.00$

$\begin{array}{rr}0.00 & -100.00 \\ 0.00 & 100.00\end{array}$

$\begin{array}{ll}0.00 & 100.00 \\ 0.00 & 100.00\end{array}$

$0.00-100.00$

$0.00 \quad 100.00$

$\begin{array}{ll}0.00 & 100.00 \\ 0.00 & 100.00\end{array}$

$0.00 \quad 100.00$

$0.00 \quad 100.00$

$0.00 \quad 100.00$

$\begin{array}{ll}1.00 & 100.00 \\ 0.00 & 100.00\end{array}$

$0.00 \quad 100.00$

0.74100 .00

$0.47 \quad 100.00$

$\begin{array}{ll}0.00 & 100.00 \\ 0.77 & 100.00\end{array}$

$0.93 \quad 100.00$

$0.00 \quad 100.00$

2.29100 .00

$0.00 \quad 100.00$

$0.00 \quad 100.00$

$2.61 \quad 100.00$

$\begin{array}{ll}0.00 & 100.00 \\ 0.00 & 100.00\end{array}$

$0.00 \quad 100.00$

$0.00 \quad 100.00$

$0.00 \quad 100.00$

$0.00 \quad 100.00$

$\begin{array}{ll}1.14 & 100.00 \\ 1.94 & 100.00\end{array}$

$0.00 \quad 100.00$

$0.00 \quad 100.00$

$0.00 \quad 100.00$

$0.00 \quad 100.00$

$0.00 \quad 100.00$

$0.00 \quad 100.00$

$0.00 \quad 100.00$

$0.00 \quad 100.00$

$0.00 \quad 100.00$

$0.00 \quad 100.00$

$0.00 \quad 100.00$

$0.00 \quad 100.00$

$0.00 \quad 100.00$

$\begin{array}{ll}0.00 & 100.00 \\ 0.00 & 100.00\end{array}$
$-75.36$

$-75.68$

$0.00-64.81$

$0.00 \quad-93.42$

$0.00 \quad-93.75$

$0.00 \quad-72.73$

$0.00 \quad-86.36$

$0.00 \quad 71.78$

$0.00 \quad 48.99$

$0.00 \quad-72.63$

$0.00 \quad 33.90$

$0.00 \quad 20.39$

$\begin{array}{ll}0.00 & 88.89 \\ 0.00 & 45.57\end{array}$

$-1.95 \quad 36.01$

$0.00 \quad 31.59$

$0.00 \quad 89.24$

$0.00 \quad 88.15$

$3.16 \quad 22.04$

0.00

0.00

$-2.75$

0.00

0.00

0.00

0.00

0.00
0.00

0.00

0.00

0.00

0.00
0.00

0.00

0.00

0.00

0.00

0.00

0.00

0.00

0.00

0.00

0.00
0.00

0.00

0.00

0.00

0.00

0.00
0.00
22.04
38.06

20.90

33.46

30.60

55.33

74.46

78.85

40.37

56.86

66.67

200.78

172.81

322.33

136.04

263.16

215.65

273.17

107.23

633.62

333.03

232.00

80.12

149.75

70.78

40.59

44.19

64.04

103.26

81.97
69.09

162.96 $\begin{array}{rr}0.00 & 37.79 \\ 0.00 & -31.07\end{array}$

$1.14 \quad 100.00$
1.94
$\mathrm{Nb}-95$

zr-95

Cs-137

\subsection{0}

0.00

0.00

0.00

0.00

0.00

0.00

$-21.65$

0.00

158.95

$-27.46$

20.26

0.00

23.25

11.07

6.47

7.99

2.85

10.32

5.39

12.36

5.73

9.39

0.00

0.00

0.00

0.00

$-3.85$

0.00

0.00

$-109.37$

0.00

0.00

0.00

0.00

0.00

12.87

24.72

10.36

0.00

0.00

0.00

$-1.39$

0.00

0.00

0.00

8.19

0.00

0.00

0.00

$-46.84$

0.00

0.00

0.00

229.63

0.00

0.00

0.00

0.00

0.00

0.00

0.00

0.00

0.00

0.00

10.77

5.09

0.00 
Table 5. Tritium Concentrations in 1993-94

(Values in $\mathrm{pci} / \mathrm{mL})^{a}$

\begin{tabular}{|c|c|c|c|c|c|}
\hline DATE & $\begin{array}{l}\text { Shell Bluff } \\
+10.0 \mathrm{mi}\end{array}$ & $\begin{array}{r}\mathrm{V} \\
+0.3 \mathrm{mi}\end{array}$ & $\begin{array}{l}\text { LE LOCATIC } \\
\text { ggtle Vic: } \\
0.0 \mathrm{mi}\end{array}$ & $\begin{array}{l}\mathrm{N}^{\mathrm{b}}- \\
\quad \operatorname{inity}^{\mathrm{c}} \\
\quad-0.1 \mathrm{mi}\end{array}$ & $\begin{array}{l}\mathrm{Hwy} 301 \\
-32.0 \mathrm{mi}\end{array}$ \\
\hline $\begin{array}{r}1 / 12 / 93 \\
2 / 09 / 93 \\
3 / 09 / 93 \\
4 / 06 / 93 \\
5 / 04 / 93 \\
6 / 01 / 93 \\
7 / 13 / 93 \\
8 / 10 / 93 \\
9 / 07 / 93 \\
10 / 19 / 93 \\
11 / 16 / 93 \\
12 / 14 / 93 \\
1 / 11 / 94 \\
2 / 08 / 94 \\
3 / 08 / 94 \\
4 / 05 / 94 \\
5 / 03 / 94 \\
6 / 14 / 94 \\
6 / 21 / 94 \\
6 / 28 / 94 \\
7 / 12 / 94 \\
8 / 09 / 94 \\
9 / 20 / 94 \\
10 / 18 / 94 \\
11 / 01 / 94 \\
12 / 13 / 94\end{array}$ & $\begin{array}{l}<0.5 \\
4.1 \pm 0.8 \\
<1.0 \\
<1.2 \\
1.9 \pm 0.6 \\
<1.2 \\
<0.5 \\
<0.8 \\
<0.9 \\
<0.8 \\
1.4 \pm 0.5 \\
<0.6 \\
<0.8 \\
<0.2 \\
<0.7 \\
2.2 \pm 0.5 \\
1.4 \pm 0.5 \\
<0.5 \\
- \\
-1 \\
<1.0 \\
<1.2 \\
<0.8 \\
<0.3 \\
<1.1 \\
<0.5\end{array}$ & $\begin{array}{l}<0.8 \\
2.5 \pm 0.7 \\
<1.2 \\
<1.2 \\
1.8 \pm 0.6 \\
<1.1 \\
<0.6 \\
<1.1 \\
<1.5 \\
<0.9 \\
1.6 \pm 0.5 \\
<0.5 \\
<0.4 \\
<0.5 \\
<1.1 \\
2.6 \pm 0.5 \\
<0.4 \\
<1.2 \\
-1 \\
<0.3 \\
<1.1 \\
<1.2 \\
<1.0 \\
<0.6 \\
<0.7 \\
<0.6\end{array}$ & $\begin{array}{l}<0.5 \\
2.8 \pm 0.8 \\
<0.8 \\
<1.1 \\
3.3 \pm 0.6 \\
1.4 \pm 0.5 \\
<1.0 \\
<1.3 \\
3.7 \pm 0.6 \\
<0.6 \\
1.8 \pm 0.5 \\
<0 \cdot 3 \\
<0.3 \\
<0.7 \\
<1 \cdot 3 \\
2.1 \pm 0.5 \\
<0.2 \\
64.0 \pm 1 \cdot 5 \\
2.6 \pm 0.5 \\
<0 \cdot 6 \\
<0.6 \\
1.3 \pm 0.4 \\
<1 \cdot 0 \\
<0.6 \\
<1 \cdot 2 \\
1.6 \pm 0.4\end{array}$ & $\begin{array}{c}<1.0 \\
4.3 \pm 0.8 \\
<1.5 \\
<1.1 \\
3.3 \pm 0.6 \\
<1.1 \\
<1.0 \\
<0.8 \\
<1.8 \\
<0.7 \\
2.5 \pm 0.5 \\
<0.6 \\
<0.4 \\
<0.7 \\
<0.8 \\
2.4 \pm 0.5 \\
<0.3 \\
56.9 \pm 1.4 \\
- \\
0.7 \pm 0.4 \\
1.1 \pm 0.5 \\
<1.3 \\
<1.0 \\
<0.7 \\
1.0 \pm 0.4 \\
<0.8\end{array}$ & $\begin{array}{l}1.4 \pm 0.5 \\
7.5 \pm 0.7 \\
1.4 \pm 0.5 \\
<1.3 \\
3.4 \pm 0.6 \\
2.4 \pm 0.5 \\
2.0 \pm 0.5 \\
1.9 \pm 0.5 \\
2.0 \pm 0.5 \\
2.2 \pm 0.5 \\
4.5 \pm 0.6 \\
1.5 \pm 0.5 \\
<1.1 \\
<1.2 \\
2.7 \pm 0.5 \\
3.8 \pm 0.5 \\
1.5 \pm 0.5 \\
1.2 \pm 0.4 \\
- \\
- \\
1.7 \pm 0.5 \\
6.4 \pm 0.6 \\
1.6 \pm 0.6 \\
1.0 \pm 0.5 \\
2.7 \pm 0.4 \\
1.4 \pm 0.4\end{array}$ \\
\hline
\end{tabular}

(a) Errors are $2 \sigma$ values (other errors in report are $1 \sigma$ ).

(b) Miles are measured upstream of Vogtle outfall.

(c) Maximum river activity on $6 / 14 / 94$ and appears to be a single occurrence associated with Vogtle, as the activity dissipated rapidly with downstream location and time. 
Table 6. Sediment concentrations in 1993-94

(Values in $\mathrm{fCi} / \mathrm{g}=\mathrm{pCi} / \mathrm{kg}$ )

\begin{tabular}{|c|c|c|c|c|c|}
\hline \multirow[t]{2}{*}{ Isotope } & \multirow[t]{2}{*}{ Date } & \multicolumn{3}{|c|}{ Vogtle Vicinity } & HwY $301^{a}$ \\
\hline & & $+0.3 \mathrm{mi}$ & $0.0 \mathrm{mi}$ & $-0.1 \mathrm{mi}$ & $-32.0 \mathrm{mi}$ \\
\hline${ }^{58} \mathrm{Co}$ & $\begin{array}{l}02 / 17 / 93 \\
05 / 11 / 93 \\
08 / 03 / 93 \\
11 / 09 / 93 \\
02 / 22 / 94 \\
05 / 24 / 94 b \\
08 / 02 / 94 \\
11 / 30 / 94\end{array}$ & $\begin{array}{r}<1.8 \\
<10.0 \\
<5.9 \\
<5.5 \\
<14.0 \\
<9.3 \\
<8.2 \\
<8.2\end{array}$ & $\begin{array}{r}<3.5 \\
<13.0 \\
<10.0 \\
<6.7 \\
<7.0 \\
<7.5 \\
<8.8 \\
<11.0\end{array}$ & $\begin{array}{r}<2.4 \\
<9.3 \\
<5.5 \\
<5.4 \\
<19.0 \\
<7.7 \\
<7.0 \\
<6.1\end{array}$ & $\begin{array}{c}<2.8 \\
<13.0 \\
<14.0 \\
29.1 \pm 5.8 \\
<17.0 \\
<10.0 \\
<10.0 \\
<6.9\end{array}$ \\
\hline${ }^{60} \mathrm{Co}$ & $\begin{array}{l}02 / 17 / 93 \\
05 / 11 / 93 \\
08 / 03 / 93 \\
11 / 09 / 93 \\
02 / 22 / 94 \\
05 / 24 / 94^{b} \\
08 / 02 / 94 \\
11 / 30 / 94\end{array}$ & $\begin{array}{l}<2.0 \\
<4.0 \\
<4.4 \\
<4.2 \\
<5.4 \\
<5.2 \\
<5.1 \\
<5.6\end{array}$ & $\begin{array}{l}<3.2 \\
<4.4 \\
<6.3 \\
<4.8 \\
<5.6 \\
<5.2 \\
<5.4 \\
<7.2\end{array}$ & $\begin{array}{r}<2.7 \\
<3.7 \\
<4.1 \\
<4.2 \\
<5.0 \\
<4.3 \\
<4.4 \\
<4.4\end{array}$ & $\begin{array}{c}<1.6 \\
<5.1 \\
<9.2 \\
30.4 \pm 2.7 \\
<4.3 \\
<5.3 \\
<5.9 \\
<4.8\end{array}$ \\
\hline${ }^{137} \mathrm{Cs}$ & $\begin{array}{l}02 / 17 / 93 \\
05 / 11 / 93 \\
08 / 03 / 93 \\
11 / 09 / 93 \\
02 / 22 / 94 \\
05 / 24 / 94^{b} \\
08 / 02 / 94 \\
11 / 30 / 94\end{array}$ & $\begin{array}{r}6.3 \pm 0.7 \\
6.2 \pm 1.4 \\
5.2 \pm 1.3 \\
13.8 \pm 1.6 \\
<3.3 \\
19.5 \pm 2.4 \\
11.2 \pm 1.8 \\
11.7 \pm 2.1\end{array}$ & $\begin{array}{r}<3.9 \\
<5.2 \\
<7.6 \\
11.0 \pm 1.9 \\
9.7 \pm 2.1 \\
6.2 \pm 1.7 \\
9.5 \pm 2.1 \\
7.9 \pm 2.5\end{array}$ & $\begin{array}{r}9.1 \pm 1.2 \\
<3.6 \\
15.6 \pm 1.8 \\
9.0 \pm 1.6 \\
15.7 \pm 1.6 \\
10.1 \pm 1.4 \\
6.1 \pm 1.6 \\
8.2 \pm 1.5\end{array}$ & $\begin{array}{r}39.5 \pm 1.5 \\
92.9 \pm 3.3 \\
112.0 \pm 5.0 \\
284.0 \pm 6.0 \\
15.9 \pm 1.6 \\
98.0 \pm 2.9 \\
108.0 \pm 3.0 \\
109.0 \pm 3.0\end{array}$ \\
\hline
\end{tabular}

(a) Miles are measured upstream of Vogtle outfall.

(b) Date $=6 / 21 / 94$ for sample at $0.0 \mathrm{mi}$. 


\section{Table 7. Comparison of Maximum 1987-1994 Levels with Guides for Drinking water}

All measured levels are from samples $0.1 \mathrm{mi}$ downstream of Vogtle outfall unless specified otherwise.

Isotope

Maximum Concentration ( $\mathrm{pCi} / \mathrm{L})$

1987-89 1990-92 1993-94 DOE Guide EPA $^{\mathrm{a}}$ CFR

$\begin{array}{lrrrrr}{ }^{3} \mathrm{H} & 47,300^{\mathrm{c}} & 42,600^{\mathrm{c}} & 64,000^{\mathrm{c}} & 2,000,000 & 20,000 \\ { }^{51} \mathrm{Cr} & 3.7 & 0.08 & 1.0 & 1,000,000 & 6000 \\ { }^{54} \mathrm{Mn} & 0.61 & 0.03 & 0.17 & 50,000 & 300 \\ { }^{57} \mathrm{Co} & 0.02 & 0.005 & 0.03 & 100,000 & - \\ { }^{58} \mathrm{Co} & 16.8 & 2.37 & 1.81 & 40,000 & 9000 \\ { }^{59} \mathrm{Fe} & 0.49 & 0.02 & 0.06 & 20,000 & 200 \\ { }^{60} \mathrm{Co} & 0.49 & 0.11 & 0.42 & 5,000 & 100 \\ { }^{95} \mathrm{Nb} & 0.50 & 0.12 & 0.10 & 40,000 & 300 \\ { }^{95} \mathrm{Zr} & 0.23 & 0.03 & 0.05 & 60,000 & 200 \\ { }^{137} \mathrm{Cs} & 0.39^{d} & 0.09^{\mathrm{d}} & 0.07^{\mathrm{d}} & 3,000 & 200\end{array}$

a) DOE 5400.5 (details per reference 8).

b) See reference 9, which shows that higher levels are being proposed for some of the above values.

c) Maximum value at Vogtle outfall is high relative to EPA/CFR level based on 4 annual mrem/yr dose, but the overall annual average at this location is well below EPA/CFR level. Also the river significantly dilutes these outfall levels.

d) Value at Highway 301 Bridge. 
FIGURE 1. Co-58 in savannah River in 1993-1994
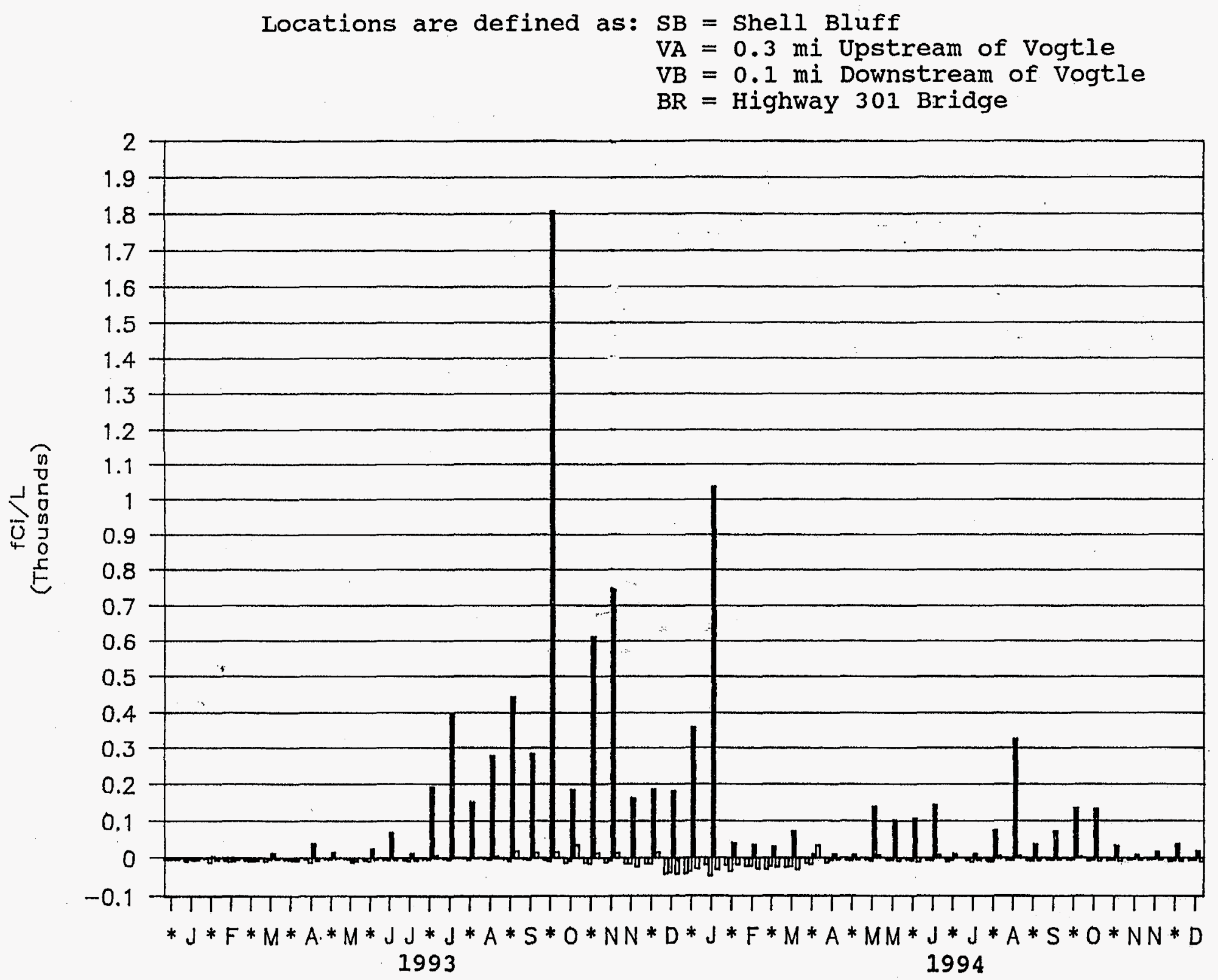

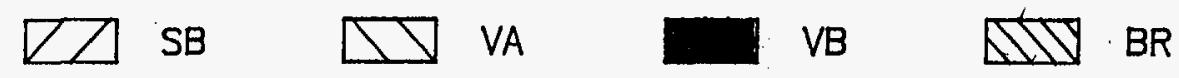




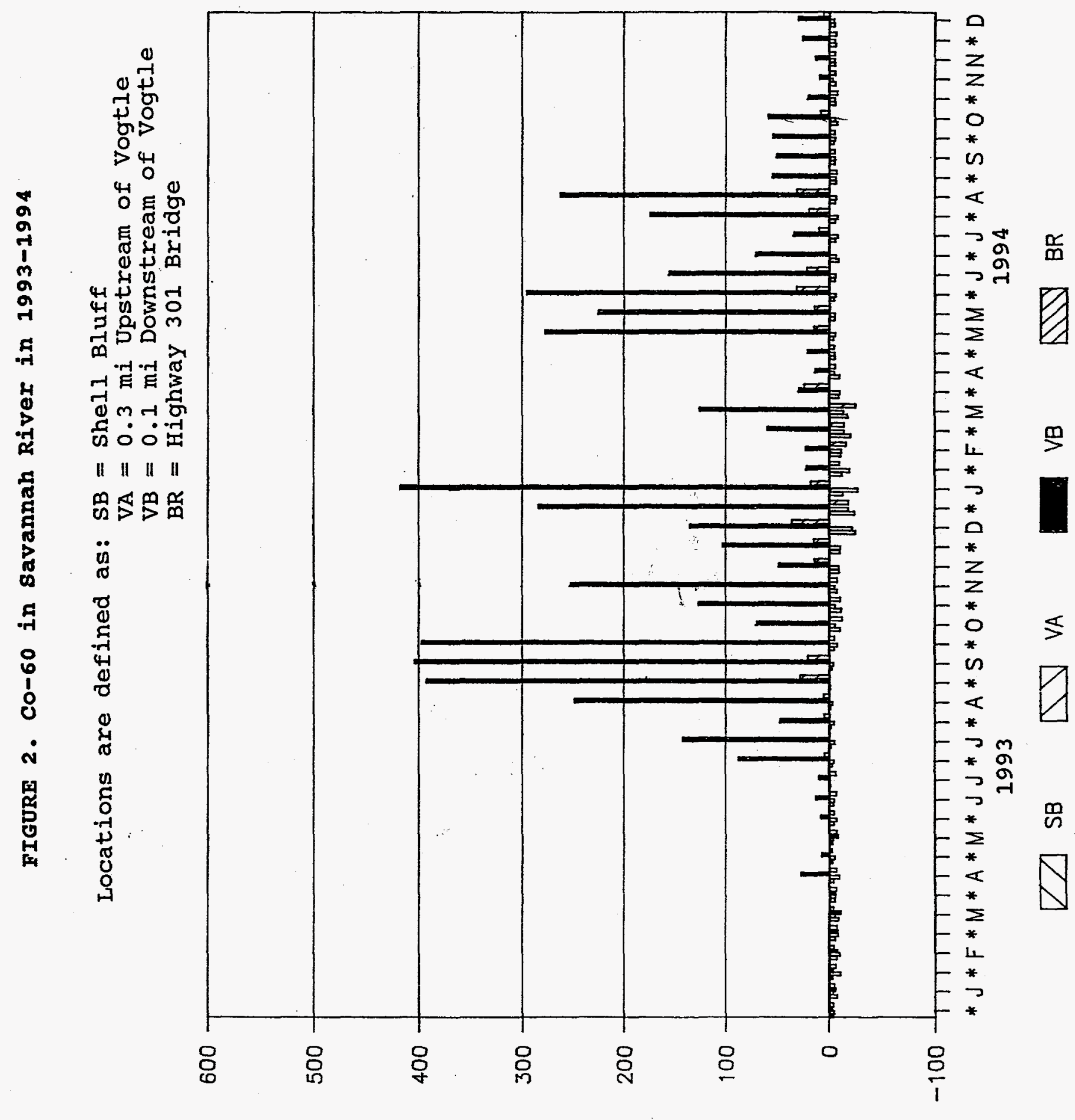

$7 / 10+$ 
FIGURE 3. Cg-137 in savannah River in 1993-1994

Locations are defined as: $S B=$ Shell Bluff

$\mathrm{VA}=0.3 \mathrm{mi}$ Upstream of Vogtle

$\mathrm{VB}=0.1 \mathrm{mi}$ Downstream of Vogtle

$\mathrm{BR}=\mathrm{Highway} 301$ Bridge
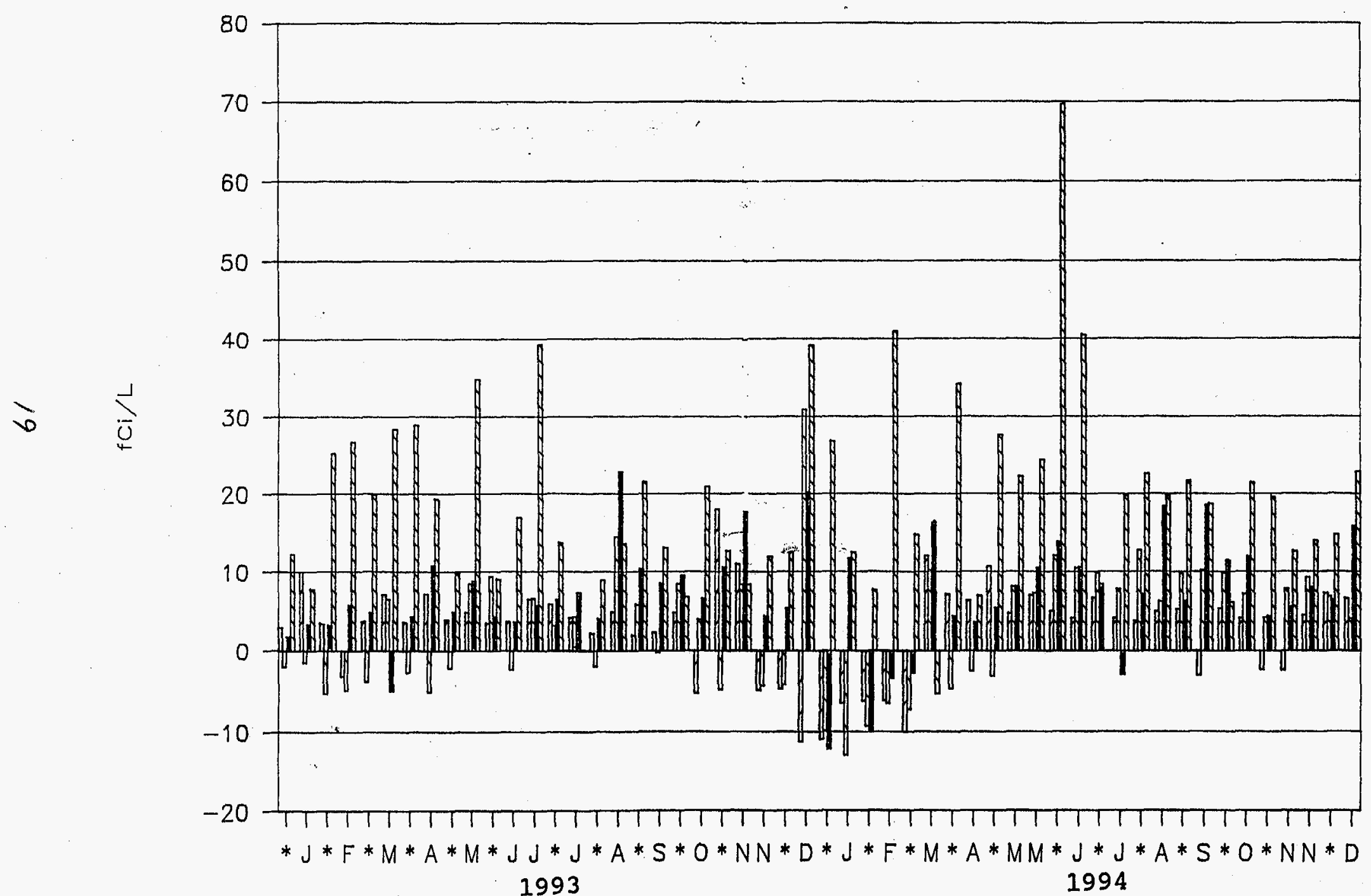

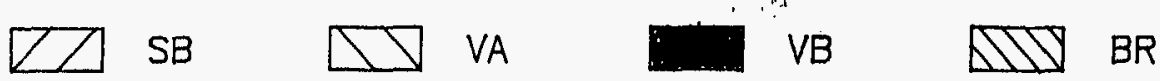


Gamma Peak keV

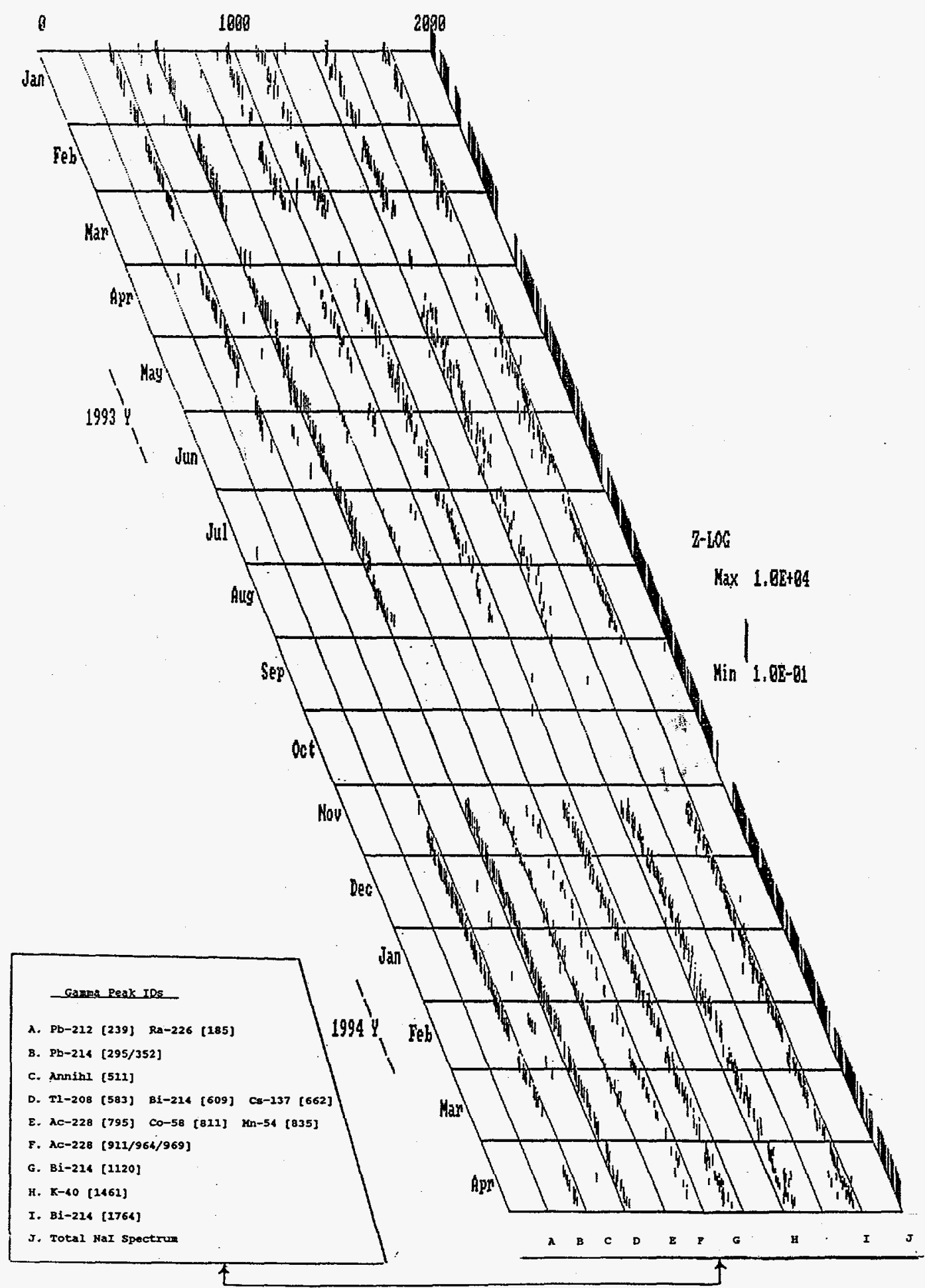

FIGURE 4. Results for Underwater NaI Detector at HwY 301 Bridge 
Hw 301 Bridge Co-58 in River

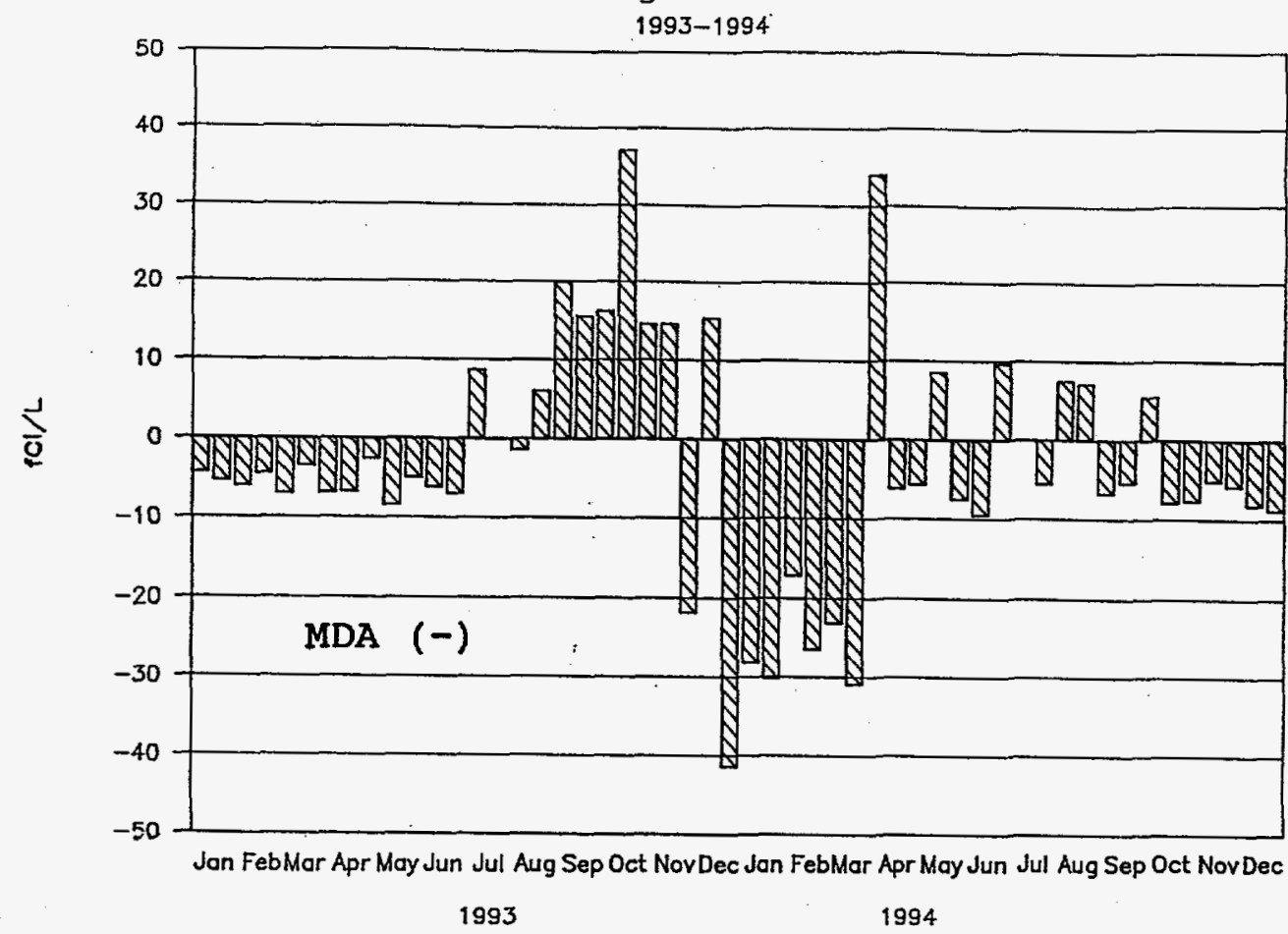

Underwater $\mathrm{Nal} \mathrm{Co-58}$

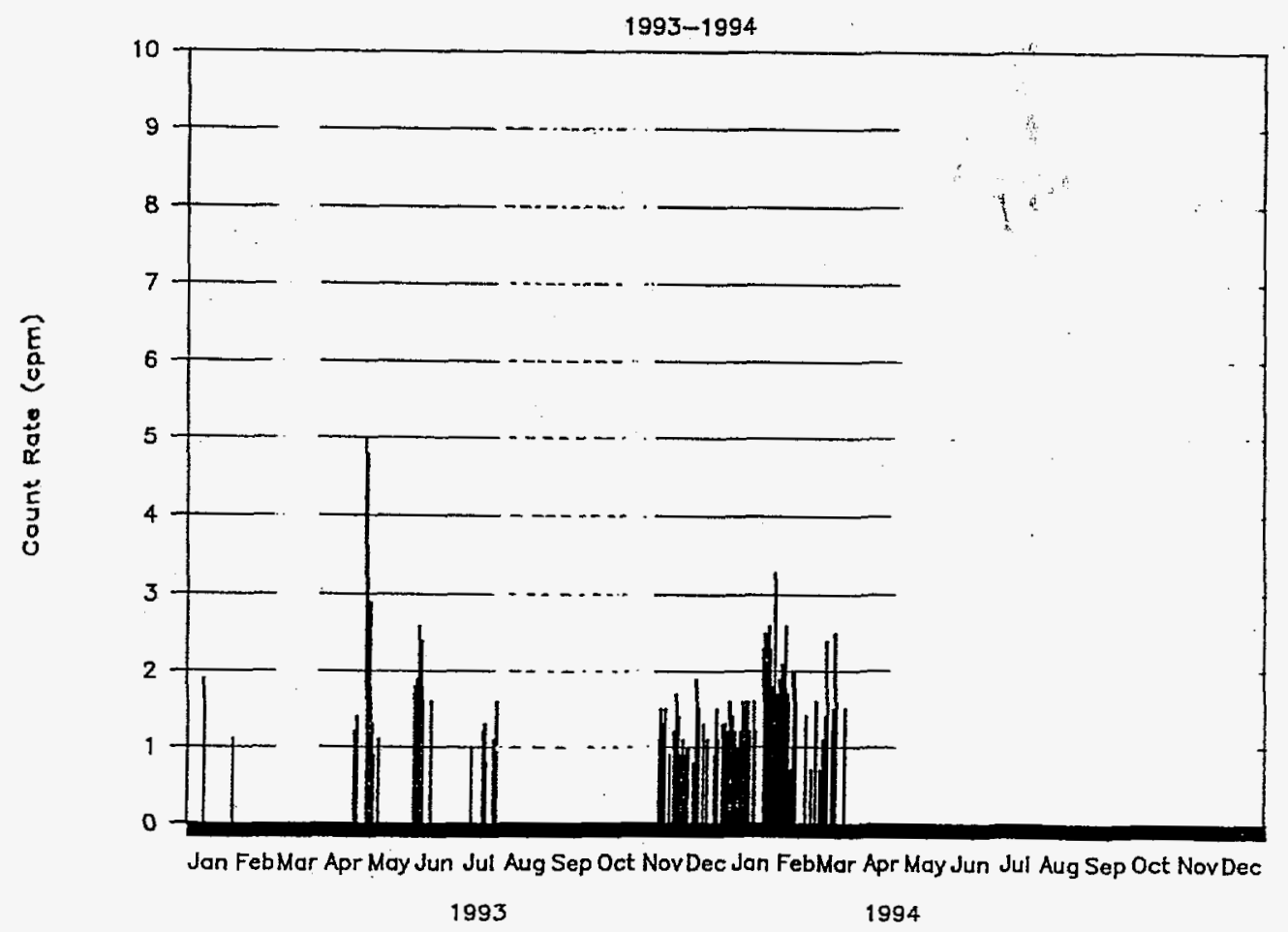

FIGURE 5. Comparison of Underwater NaI and Resin sample Results for co-58 detection at Hwy 301 Bridge

Horizontal grid lines blanked when detector out of service and dotted when resolution too poor to distinguish the Co-58 peak - refer to Figure 4 . 
Appendix - Map of sample Locations

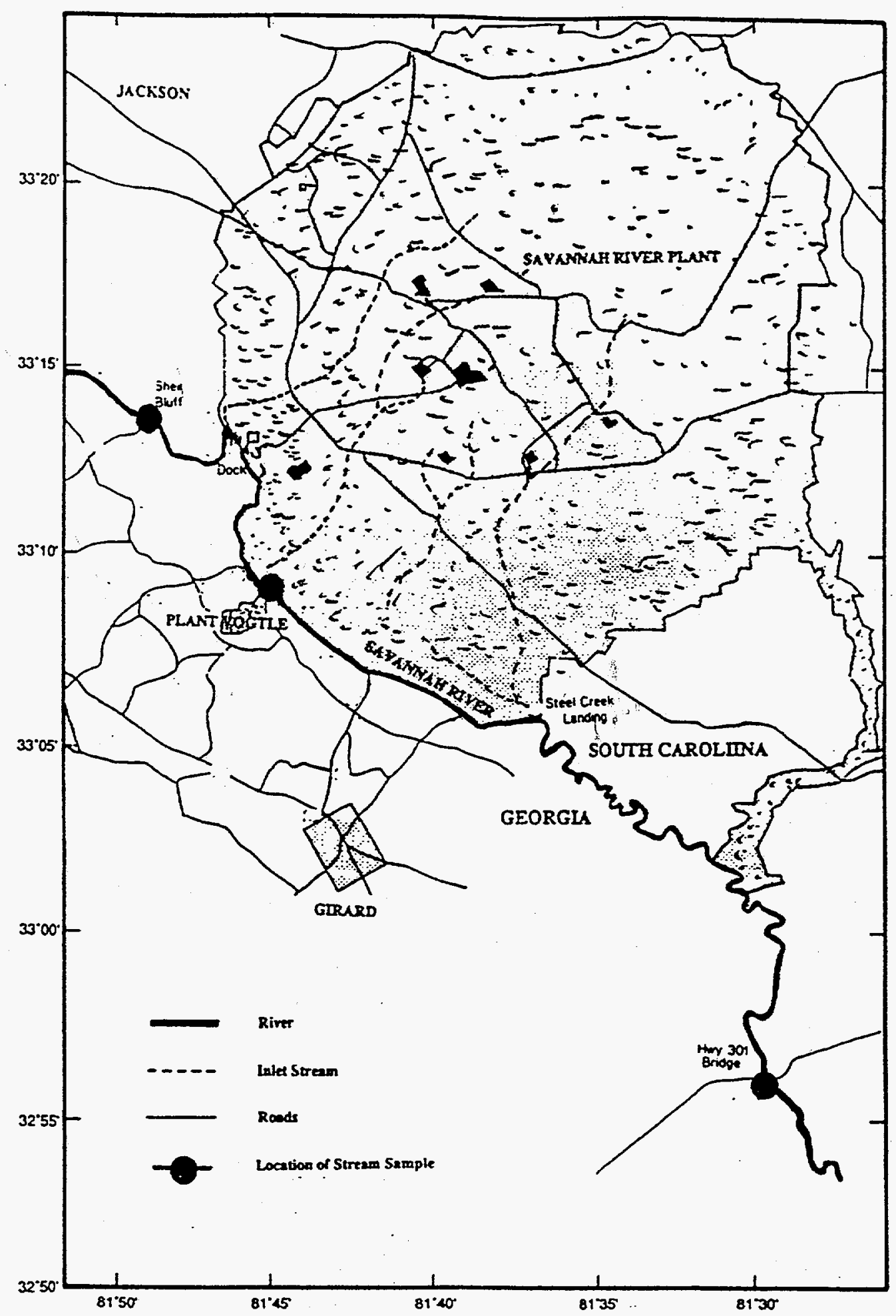

